\title{
PROGRAM PENGABDIAN MASYARAKAT MELALUI WORKSHOP ANALISIS DATA PENELITIAN PENDIDIKAN DI IAI QOMARUDDIN GRESIK
}

\author{
Anik Rufaidah ${ }^{1}$, Nailul Izzah $^{2}$, Sofiyanurriyanti ${ }^{3}$, Suparno $^{4}$, Moh. Ririn Rosyidi ${ }^{5}$ \\ 1,2,3,4,5 Program Studi Teknik Industri \\ Sekolah Tinggi Teknik Qomaruddin (STTQ) Gresik \\ Email: ti.sttqgresik@gmail.com
}

\begin{abstract}
Abstrak. This Community Service Program is one form of Tri Dharma Higher Education activities that must be carried out including Education, Research, and Community Service. One of the activities carried out in this training was in the field of education. One of them is training on data analysis workshops in the PAI department at the Qomaruddin Islamic Institute (IAIQ) Gresik. Through community service activities, it is important for lecturers to provide a distribution of knowledge and practice in the world of education. The purpose of the activity in this study is that lecturers can implement theories in lectures at the center of society and to analyze final assignment data using statistics and application software. The method of this research is a mixture of quantitative and qualitative methods with descriptive analysis techniques. The sample of this study was 120 students majoring in PAI at IAI Qomaruddin Gresik. Implementation methods used in activities include: 1) Simple linear regression training, 2) Training in statistical hypothesis determination, 3) Descriptive statistical training, 4) Data analysis. The research was conducted on Sunday, March 10, 2016 at the Qomaruddin Gresik IAI Hall. Data collection tools and techniques are guidelines for study documentation, training, focus group discussions (FGD) and question and answer questions for students. Benefits achieved in PPM activities include lecturers having analytical and conceptual abilities through real activities in the community and being able to learn directly from the community. IAI PAI POMaruddin Students can analyze data by applying the application of statistical science to Final Project data. Qomaruddin Gresik College, especially in the Department of Islamic Education IAI Qomaruddin. In the PKM activity on the training "Data Analysis Workshop for Research in Education at the Department of Islamic Studies of the Qomaruddin Islamic Institute (IAIQ) until Gresik Bungah". The results of this training show the level of success obtained in these activities including to describe data by representing the value of data concentration and the value of data dissemination and can group large amounts of data into the form of frequency distribution, Training with Hypothesis analysis material on estimating average values, the hypothesis of the estimated value of variance and the hypothesis of the estimated value of proportions, in the regression analysis the form of the model between independent variables with non-independent variables in which the two variables are interconnected in the form of models $Y=\alpha+\beta X+\varepsilon$, and can apply with applications in MINITAB software and SPSS.
\end{abstract}

Keywords: Research, Public Service, College, Data Analysis

\begin{abstract}
Program Pengabdian Masyarakat ini merupakan salah satu bentuk kegiatan Tri Dharma Perguruan Tinggi yang wajib dilakukan antara lain Pendidikan, Penelitian, dan Pengabdian Masyarakat. Salah satu kegiatan yang dilakukan pada pelatihan ini, adalah dibidang pendidikan. Salah satunya adalah pelatihan tentang workshop analisis data di jurusan PAI di Institut Agama Islam Qomaruddin (IAIQ) Gresik. Melalui kegiatan pengabdian masyarakat memiliki arti penting bagi dosen untuk memberikan distribusi ilmu dan praktek di dalam dunia pendidikan. Tujuan dari kegiatan pada penelitian ini adalah Dosen dapat mengimplementasikan teori-teori dalam perkuliahan saat ditengah masyarakat dan untuk menganalisi data tugas akhir dengan menggunakan ilmu statistika dan software aplikasinya. Metode penelitian ini adalah metode campuran kuantitatif dan kualitatif dengan teknik analisis deskriptif. Sampel penelitian ini berjumlah 120 mahasiswa jurusan PAI di IAI Qomaruddin Gresik. Metode pelaksanaan yang digunakan pada kegiatan antara lain: 1) Pelatihan regresi linier sederhana, 2) Pelatihan penentuan hipotesis statistik,3) Pelatihan statistika deskriptif, 4) Analisis Data. Penelitian dilaksanakan pada hari minggu 10 Maret 2016 bertempat di Aula IAI Qomaruddin Gresik. Alat dan teknik pengumpulan data adalah pedoman studi dokumentasi, pelatihan, focus group discussion (FGD) serta tanya jawab terhadap mahasiswa. Manfaat yang dicapai dalam kegiatan PPM antara lain Dosen memiliki kemampuan analisis dan konseptual lewat kegiatan nyata dalam masyarakat serta dapat belajar langsung dari masyarakat, Mahasiswa Jurusan PAI IAI Qomaruddin dapat menganalisis data dengan menerapkan aplikasi ilmu statistika pada data Tugas Akhir, Bertambahnya mitra kerja Sekolah Tinggi Teknik Qomaruddin Gresik Perguruan Tinggi, khususnya diJurusan PAI IAI Qomaruddin. Dalam kegiatan PKM tentang pelatihan "Workshop Analisis Data Untuk Penelitian Di Bidang Pendidikan di
\end{abstract}


Jurusan PAI Institut Agama Islam Qomaruddin (IAIQ) sampurnan Bungah Gresik”. Hasil kegiatan pelatihan ini menunjukkan tingkat keberhasilan yang didapatkan dalam kegiatan tersebut diantaranya untuk mendiskriptifkan data dengan mewakili nilai pemusatan data dan nilai penyebaran data dan bisa mengelompokkan data yang jumlahnya besar kedalam bentuk distribusi frekuensi, Pelatihan dengan materi analisis Hipotesis pada pendugaan terhadap nilai rata-rata, hipotesis terhadap nilai dugaan variansi dan hipotesis terhadap nilai dugaan proporsi, pada analisis regresi bentuk model anatara variabel bebas dengan variabel tak bebas yang mana kedua variabel tesebut saling berhubungan berupa model $Y=\alpha+\beta X+\varepsilon$, serta dapat mengaplikasikan dengan aplikasi pada software MINITAB dan SPSS.

Keywords: Penelitian, Pengabdian Masyarakat, Perguruan Tinggi, Analisis Data

\section{PENDAHULUAN}

Perguruan Tinggi merupakan sautu jenjang pendidikan yang dijalanin oleh seseorang setelah selesai menempuh pendidikan sekolah menengah atas, didalam perguruan tinggi seseorang akan mempelajari suatu disiplin ilmu yang secara spesifik mempelajari ilmu hukum, teknik, kedokteran, sosial, ekonomi, sastra dan lainnya (Kamus Besar Bahasa Indonesia, 2012). Selain itu dengan menempuh pendidikan diperguruan tinggi mahasiswa juga mendapatkan ilmu serta wawasan pengetahuan yang didapatkan dikehidupan sehari-hari dan berguna untuk masa depan. Untuk meningkatkan kualitas akademik, disamping kegiatan perkuliahan regular, diselenggarakan beberapa aktifitas akademik, seperti disukusi bulanan, bedah buku, seminar tentang keagamaan, kepesantrenan, kependidikan, ekonomi, politik dan kemasyarakatan, penataran jurnalistik, managemen, metologi penelitian, analisis lintas wacana, dan kepemimpinan mahasiswa. Disamping itu ikut berperan dalam berbagai kegiatan seminar, lokakarya dan penataran diluar kampus. Dalam bidang penelitian, dosen IAI Qomaruddin Gresik aktif melakukan penelitian kependidikan dan kemasyarakatan antara lain: keberadaan metodologi pengajaran guru agama dalam hubungannya meningkatkan prestasi belajar siswa MI, MTs Ma'arif se Kabupaten Gresik, pelaksanaan evaluasi PBM di IAI Qomaruddin, studi tentang pengembangan metode pengajaran Bahasa Arab, Efisiensi Perpustakaan bagi Mahasiswa, Pengaruh dana Bantuan Pemerintah terhadap Peningkatan Mutu Pendidikan di Gresik, Biaya Minimal Pendidikan di Kabupaten Gresik, dan masih banyak penelitian lain baik yang dilakukan secara mandiri maupun kelompok, baik dengan dana IAI
Qomaruddin atau pihak-pihak lain yang berkepentingan. Melihat kebutuhan yang semakin luas bagi pengembangan Dosen dan Mahasiswa serta sebagai perwujudan peran perguruan tinggi dalam menentukan kebijakan pemerintahan sudah dirintis dan dilaksanakan kerjasama dengan pemerintahan Kabupaten Gresik, Dewan Pendidikan Gresik, serta instansi lain yang terkait dengan pengembangan pendidikan, ekonomi, politik, sosial budaya dan keagamaan.

Adapun kegiatan pengabdian msyarakat yang dilakukan sampai tahun akademi 2015/2016 adalah pelaksanaan Kuliah Kerja Nyata (KKN) di wilayah Kabupaten Gresik dengan sasaran daerah yang minus Agama surplus ekonomi dan daerah minus ekonomi surplus agama. IAI Qomaruddin memiliki 4 desa binaan yang tersebar di wilayah Kecamatan Bungah, Dukun, Ujungpangkah dan Panceng. Aspek yang diperioritaskan dalam pembinaan adalah; peningkatan kualitas keberagamaan melalui pendirian Madrasah Diniyah, TPQ, khutbah Jum'at, pengajian rutin, peningkatan mutu penididikan dan peran serta masyarakat dalam pendidikan, peningkatan mutu ekonomi masyarakat dengan pemberdayaan pundit-pundi ekonomi kerakyatan, peningkatan fungsi control masyarakat dengan pendidikan civil society dan lain sebagainya (IAQ, 2016).

Berdasarkan analisis situasi, terdapat beberapa permasalahan yang akan diangkat dalam Pengabdian Pada Masyarakat (PPM), antara lain 1) Bagaimana Dosen dapat mengimplementasikan teori-teori dalam perkuliahan terhadap kasus yang ada secara nyata, 2) Bagaimana cara menganalisis data TA dengan menggunakan ilmu statistika dan aplikasinya. Sedangkan tujuan dalam kegiatan ini PPM antara lain 1) Dosen dapat mengimplementasikan teori-teori dalam 
perkuliahan saat ditengah masyarakat serta 2) Untuk menganalisis data TA dengan menggunakan ilmu statistika dan cara aplikasi penggunaannya. Manfaat yang dicapai dalam kegiatan PPM antara lain sebagai berikut:

Dosen memiliki kemampuan analisis dan konseptual lewat kegiatan nyata dalam masyarakat serta dapat belajar langsung dari masyarakat, Mahasiswa Jurusan PAI IAI Qomaruddin dapat menganalisis data dengan menerapkan aplikasi ilmu statistika pada data Tugas Akhir dan Bertambahnya mitra kerja Sekolah Tinggi Teknik Qomaruddin Gresik Perguruan Tinggi, khususnya diJurusan PAI IAI Qomaruddin Gresik.

\section{METODE PELAKSANAAN}

Metode penelitian yang digunakan adalah metode kuantitatif dan kualitatif dengan teknik analisis deskriptif.

Penelitian ini dilaksanakan pada hari Minggu, tanggal 10 Maret 2016 bertempat di Aula IAI Qomaruddin Gresik. Pelatihan ini dilakukan sebanyak 120 orang mahasiswa yang berasal dari jurusan PAI.

Metode pendekatan yang dilakukan untuk mencapai tujuan pengabdian kepada masyarakat yang telah di tentukan sebagai berikut :

1. Melakukan persiapan untuk mengetahui kondisi tempat di Institut Agama Islam Qomaruddin Bungah Gresik

2. Melakukan koordinasi dengan Kepala LPPM IAIQ dan mahasiswa

3. Memberikan pelatihan tentang "Workshop Analisis Data untuk Penelitian di Bidang Pendidikan di Jurusan PAI IAIQ Sampurnaan Bungah Gresik"

\section{Realisasi Pemecahan Masalah}

Sesuai dengan kerangka pemecahan masalah diatas, maka dilakukan perancangan untuk merealisasikannya. Berikut adalah tahapan dalam merealisasikan pemecahan masalah yang telah ditetapkan sebelumnya
1. Memberikan surat permohonan pelatihan kepada kepala LPPM IAIQ.

2. Berdasarkan informasi dari Kepala LPPm IAIQ, maka tim pengabdian masyarakat program studi teknik Industri STTQ Gresik, mengundang mahasiswa jurusan PAI terutama mahasiswa semester akhir untuk mengikuti pelatihan tersebut.

3. Setiap mahasiswa yang hadir diwajibkan membawa laptop.

4. Tim pengabdian masyarakat program studi Teknik Industri STTQ Gresik menyiapkan software SPSS versi 16 dan Minitab untuk diinstal pada masing-masing computer peserta pelatihaan.

5. Untuk memandu proses penginstalan, tim pengabdian masyarakat program studi Teknik Industri dibantu oleh 9 mahasiswa Teknik Industri.

6. Setiap peserta pelatihan dilatih memecahkan masalah menggunakan software SPSS dan Minitab untuk melakukan analisa data.

7. Hasil akhir dari pelatihan ini adalah kemampuan mahasiswa IAIQ untuk Meningkatkan mengolah data melalui pelatihan "Workshop Analisis Data Untuk Penelitian Di Bidang Pendidikan di Jurusan PAI Institut Agama Islam Qomaruddin (IAIQ) sampurnan Bungah Gresik".

\section{Metode yang Digunakan}

Dalam kegiatan PKM tentang pelatihan "Workshop Analisis Data Untuk Penelitian Di Bidang Pendidikan di Jurusan PAI Institut Agama Islam Qomaruddin (IAIQ) sampurnan Bungah Gresik" tahun 2018 terdapat beberapa kegiatan yang telah dilakukan.

1. Pelatihan Regresi Linier

2. Pelatihan Penentuan Hipotesis Statistik

3. Pelatihan Statiska Deskriptif

4. Analisis Data 
Tabel 1. Metode Pelaksanaan Kegiatan

\begin{tabular}{|c|c|c|}
\hline No & Materi & Metode \\
\hline 1 & $\begin{array}{l}\text { Pelatihan Regresi Linier } \\
\text { Sederhana }\end{array}$ & $\begin{array}{l}\text { Peserta pelatihan diarahkan untuk melakukan: } \\
\text { Uji asumsi model; } \\
\text { Plot antara residual dengan observasi yang juga tidak } \\
\text { berpola atau plot tersebut acak; } \\
\text { Plot Distribusi Normal yaitu bagaimana pola residual } \\
\text { apakah mendekati distribusi normal dengan melihat } \\
\text { normality plot, yang mana bentuk distribusi normal } \\
\text { dengan melihat plot tersebut mengikuti garis lurus; } \\
\text { Studi kasus. }\end{array}$ \\
\hline 2 & $\begin{array}{l}\text { Pelatihan Penentuan Hipotesis } \\
\text { Statistik }\end{array}$ & $\begin{array}{l}\text { 1. Menguji apakah hipotesis penelitian yang telah } \\
\text { terbukti atau tidak terbukti berdasarkan data } \\
\text { sampel tersebut dapat diberlakukan pada populasi } \\
\text { atau tidak; } \\
\text { 2. Menentukan Teori Sebagai Acuan Perumusan } \\
\text { Hipotesis, dimana mahasiswa diminta } \\
\text { menurunkan sebuah teori menjadi sejumlah } \\
\text { asumsi dan prostulat; } \\
\text { 3. Menentukan Fakta Ilmiah sebagai acuan } \\
\text { perumusan hipotesis dapat diperoleh dengan cara: } \\
\text { a. Memperoleh dari sumber aslinya } \\
\text { b. Fakta yang diidentifikasi dengan cara } \\
\text { menggambarkan dan menafsirkannya dari } \\
\text { sumber yang asli. } \\
\text { c. Fakta yang diperoleh dari orang } \\
\text { mengidentifikasi dengan jalan menyusunnya } \\
\text { dalam bentuk abstract reasoning (penalaran } \\
\text { abstrak). } \\
\text { 4. Fakta yang telah terkumpul dibuat dalam bentuk } \\
\text { studi kasus dan dipecahkan menggunakan } \\
\text { minitab; } \\
\text { 5. Perwakilan satu orag dari masing-masing } \\
\text { kelompok untuk mempresentasikan hasil. }\end{array}$ \\
\hline 3 & Pelatihan Statistika Deskriptif & $\begin{array}{l}\text { Peserta pelatihan diminta untuk bisa melakukan : } \\
\text { a. Ukuran pemusatan data; } \\
\text { b. Rata-rata distribusi duatu data; } \\
\text { c. Median; } \\
\text { d. Modus; } \\
\text { e. Jangkauan suatu data; } \\
\text { f. Variasi; } \\
\text { g. Standard deviasi; } \\
\text { h. Tabel distribusi frekuensi; } \\
\text { i. Studi kasus. }\end{array}$ \\
\hline 4 & Analisis Data & $\begin{array}{l}\text { Peserta pelatihan diarahkan untuk melakukan: } \\
\text { a. Pengeditan data mentah; } \\
\text { b. Tahap pemberian kode (koding); } \\
\text { c. Menyusun tabulasi data; } \\
\text { d. Verifikasi data penelitian; }\end{array}$ \\
\hline
\end{tabular}

Sumber: Data diolah 


\section{HASIL DAN PEMBAHASAN}

Hasil dari pembahasan dapat dikemukakan sebagai berikut :

1. Pelatihan Analisis Diskriptif Statistik

Pemberian pelatihan dengan materi Analisis Diskriptif pada pengolahan data Tugas akhir di Jurusan PAI Perguruan tinggi IAI Qomaruddin Gresik pada mahasiswa yang melakukan pengambilan Tugas Akhir (TA). Pelatihan ini diberikan dengan tujuan untuk memberikan pengetahuan kepada mahasiswa yang sedang Tugas Akhir bagaimana untuk mendiskriptifkan data dengan mewakili nilai pemusatan data dan nilai penyebaran data, dan juga bagaimana kita bisa mengelompokkan data tang jumlahnya besar kedalam bentuk distribusi frekuensi. Peserta pelatihan diperkenalkan bagaimana membuat kuesioner, menentukan variabel yang akan diteliti, dan kemudian mencari nilai pemusatan dan penyebaran data tersebut dan juga membuat distribusi frekuensi dari data yang jumlahnya besar. Pada pelatihan tersebut, peserta diberi studi kasus dari masalah real yang dihadapi di lapanganHasil akhir peserta diperkenalkan bagaimana mencari nilai pemusatan data penyebaran data tersebut.

2. Pelatihan Analisis Hipotesis

Pelatihan dengan materi analisis Hipotesis pada pendugaan terhadap nilai rata-rata, hipotesis terhadap nilai dugaan variansi dan hipotesis terhadap nilai dugaan proporsi pada mahasiswa tugas akhir di Jurusan PAI IAI Qomaruddin. Pelatihan ini diberikan dengan tujuan untuk memberikan pemahaman kepada peserta yang merupakan mahasiswa yang sedang mengerjakan Tugas Akhir di Jurusan PAI lingkungan IAI Qomaruddin, bagaimana kita menyelesaikan masalah dengan menduga populasi lewat sampel yang diamanti oleh peneliti. Dugaan tersebut bisa berupa dugaan terhadap ratarata, dugaan terhadap varians dan dugaan terhadap proposi dari sampel terhadap populasi yang ada. Dan juga dalam pelatihan tersebut, peserta diberi studi kasus dari masalah real yang dihadapi di lapangan. Hasil akhir peserta diperkenalkan untuk bagaimana menyelesaikan suatu masalah yang berhubungan dengan analisis hipotesis tersebut.

3. Pelatihan Analisis Regresi Sederhana Pelatihan dengan materi Analisis Regresi pada mahasiswa Tugas Akhir dilingkungan jurusan PAI dan KI IAI Qomaruddin. Pada analisis Regresi ini bagaimana bentuk model anatara variabel bebas dengan varibel tak bebas yang mana kedua varibel tesebut saling berhubungan. Pada awalny peserta diajari untuk menentukan seberapa besar hubungan atara variabel bebas dengan varibel tak bebas tersebut dengan menggunakan analisis korelasi. Dalam perhitungan analisis korelasi jika antara varibel bebas dan varibel tak bebas ada hubungan dengan ditunjukkan besarnya nilai korelasi yang mendekati 1 , sehingga dapar dicari model yang sesuai terhadap hubungan dua varibel tersebut yang berupa model $\mathrm{Y}=\alpha+\beta \mathrm{X}+\varepsilon$. Sehingga dapat dilihat seberapa besar pengaruh varibel bebas terhadap varibel tak bebas tersebut. Pada pelatihan analisis Regresi ini para peserta diberi studi kasus tentang bagaimana cara menghitung nilai korelasi, dan taksiranraksiran regresi tersebut.

4. Pelatihan Aplikasi Software MINITAB dan SPSS

Pelatihan pada Aplikasi Software MINITAB dan SPSS pada peserta mahasiswa Tugas Akhir di Lingkungan IAI Qomaruddin. Pelatihan ini dapat diharapkan para peserta dapat mengaplikasikan analisis-analisis statistika tersebut dengan bantuan perhitungan aplikasi pada Software MINITAB dan SPSS tersebut.pelatihan ini para peserta diberi studi kasus tentang analisis diskriptif, distribusi frekuensi, analisis Hipotesis terhadap rata-rata, hipotesis terhadap variansi dan hipotesis terhadap proporsi, dan juga analisis korelasi dan analisis regresi, semua penerapannya akan dilakukan perhitungan dengan bantuan aplikasi MINITAB dan SPSS, sehingga para peserta mudah untuk mendapatkan hasil 
yang diperoleh meskipun dengan jumlah data yang sangat besar (big data). kepada masyarakat kepada mahasiwa Qomaruddin sebagai berikut:

Dokumentasi pelaksanaan kegiatan pengabdian

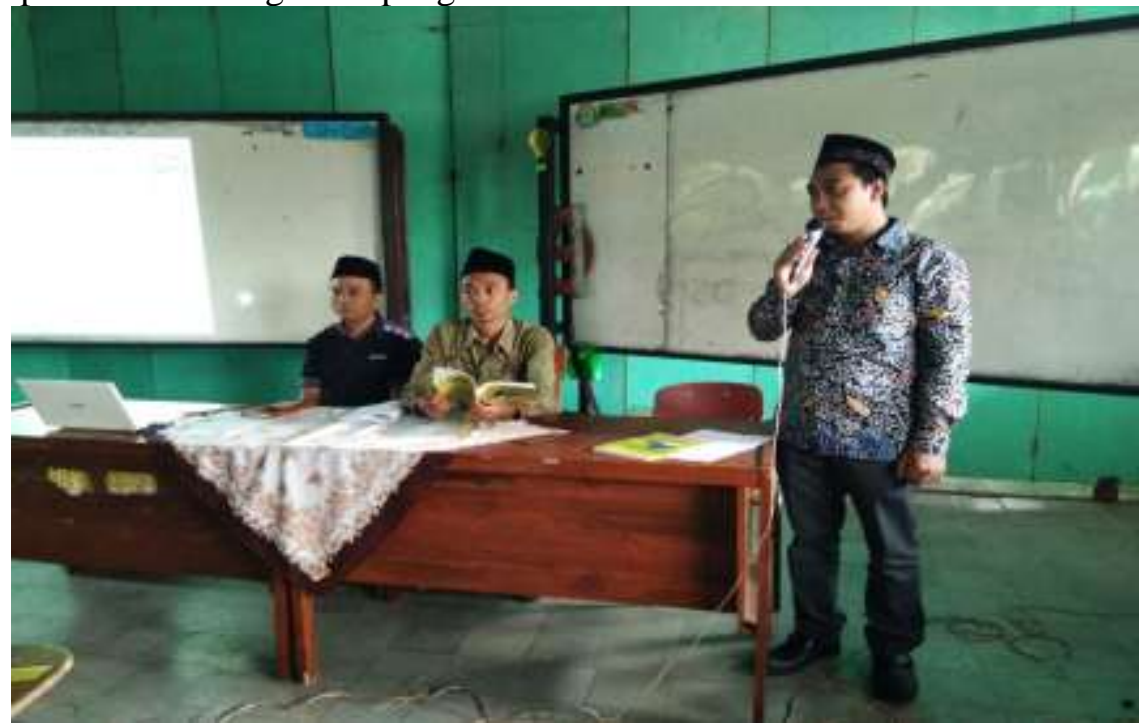

Gambar 1. Sambutan oleh kepala jurusan Program Studi Teknik Industri disambut oleh Ketua LPPM IAI Qomaruddin Gresik

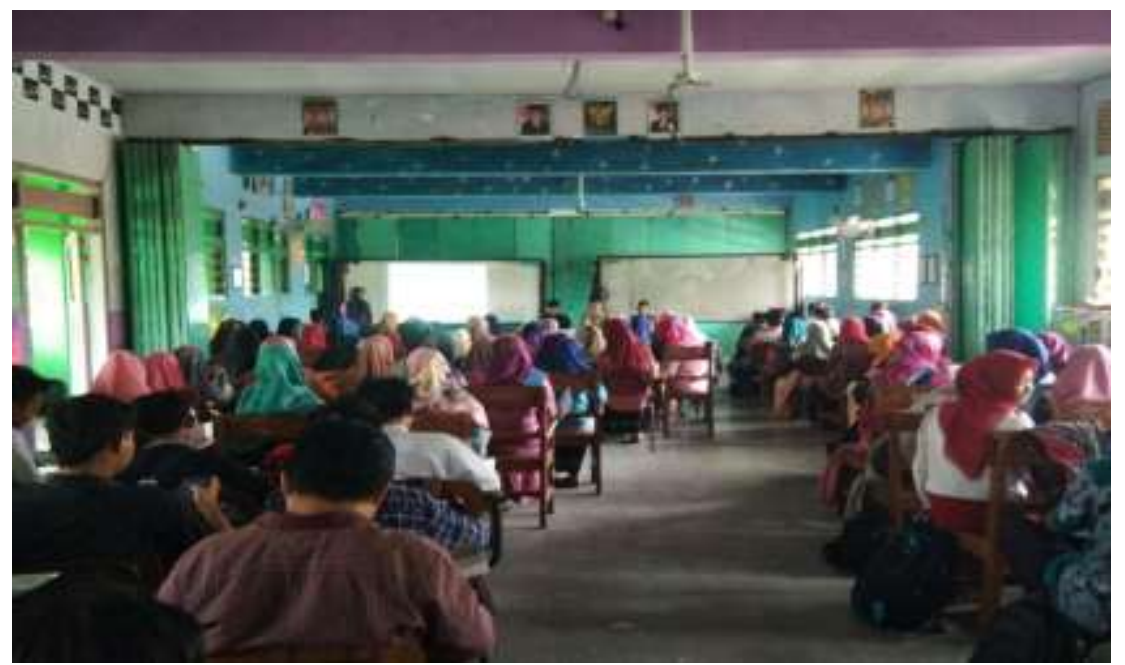

Gambar 2. Kegiatan dilakukan di AULA IAI Qomaruddin Gresik

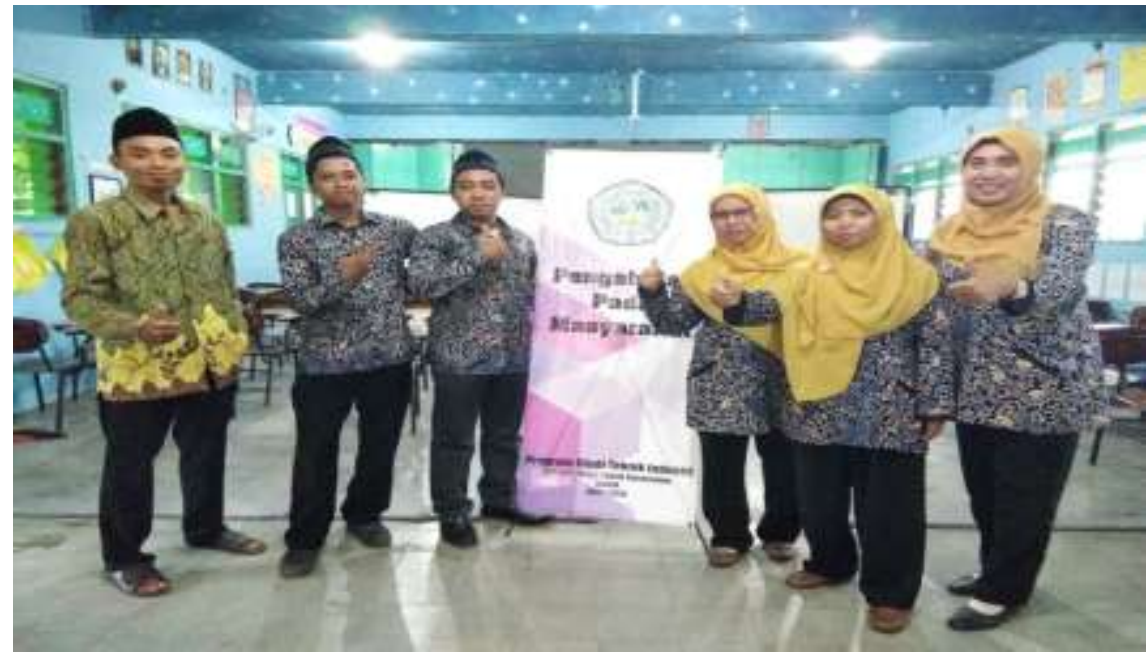

Gambar 3. Tim Dosen Program Studi Teknik Industri beserta Ketua LPPM IAI Qomaruddin Gresik 


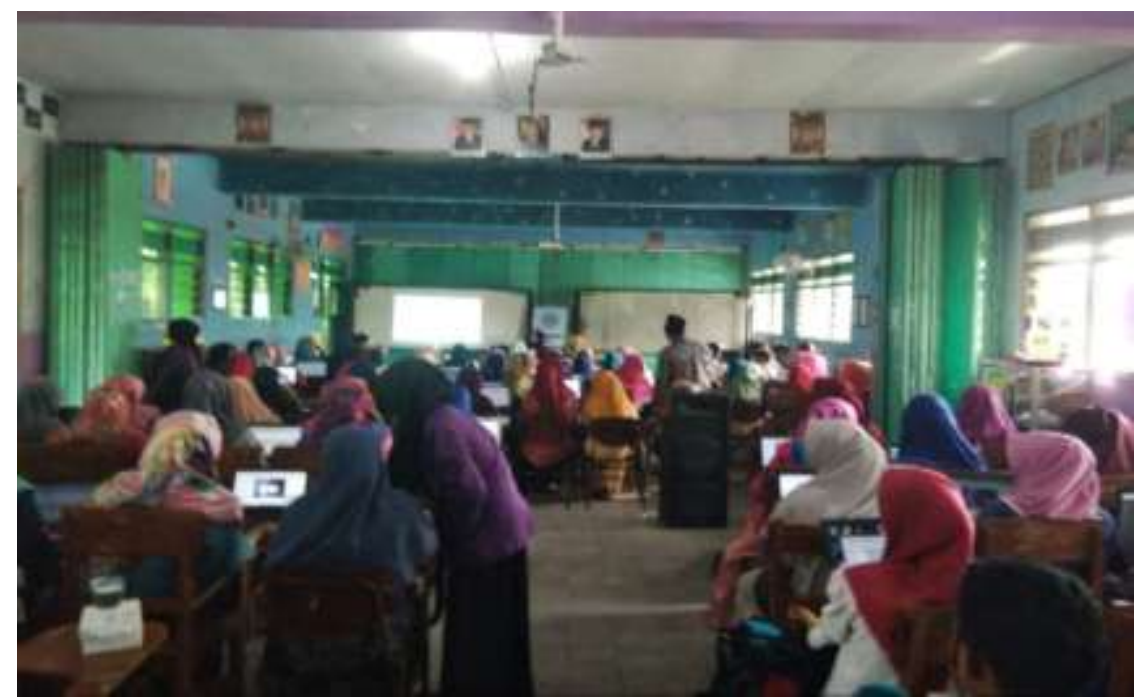

Gambar 4. Persiapan kegiatan pelatihan dengan mengeluarkan laptop masing-masing

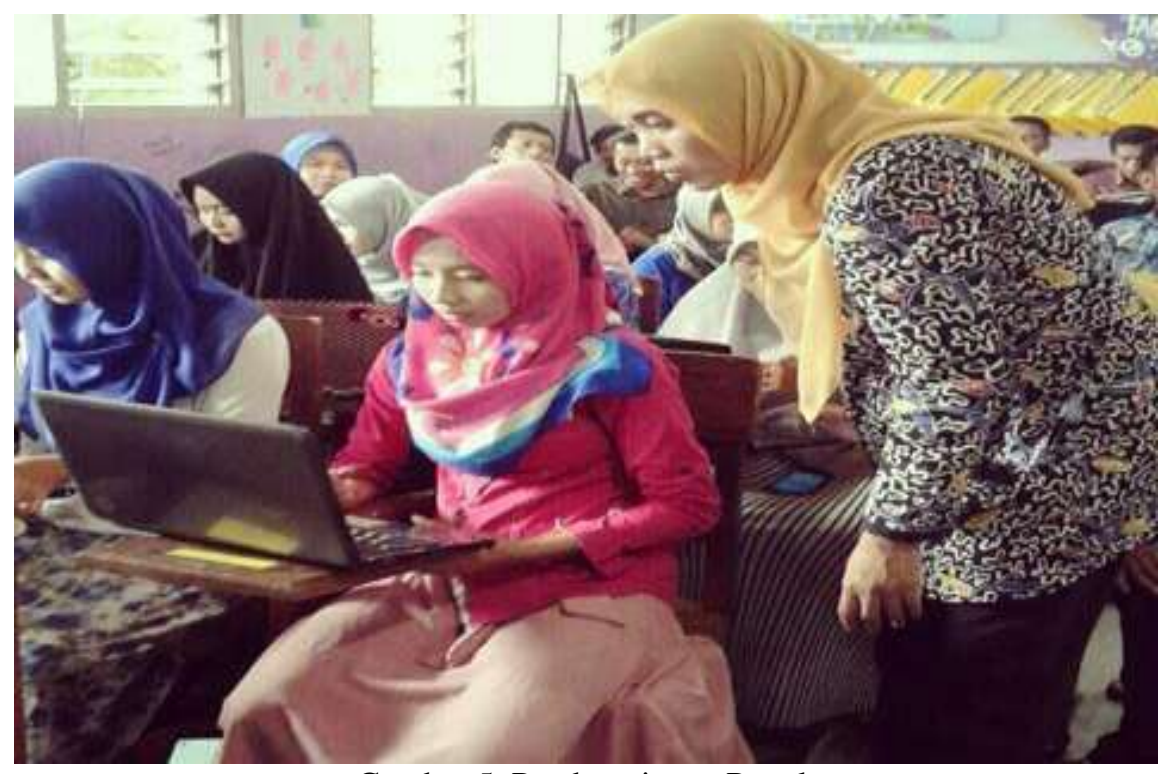

Gambar 5. Pendampingan Pratek

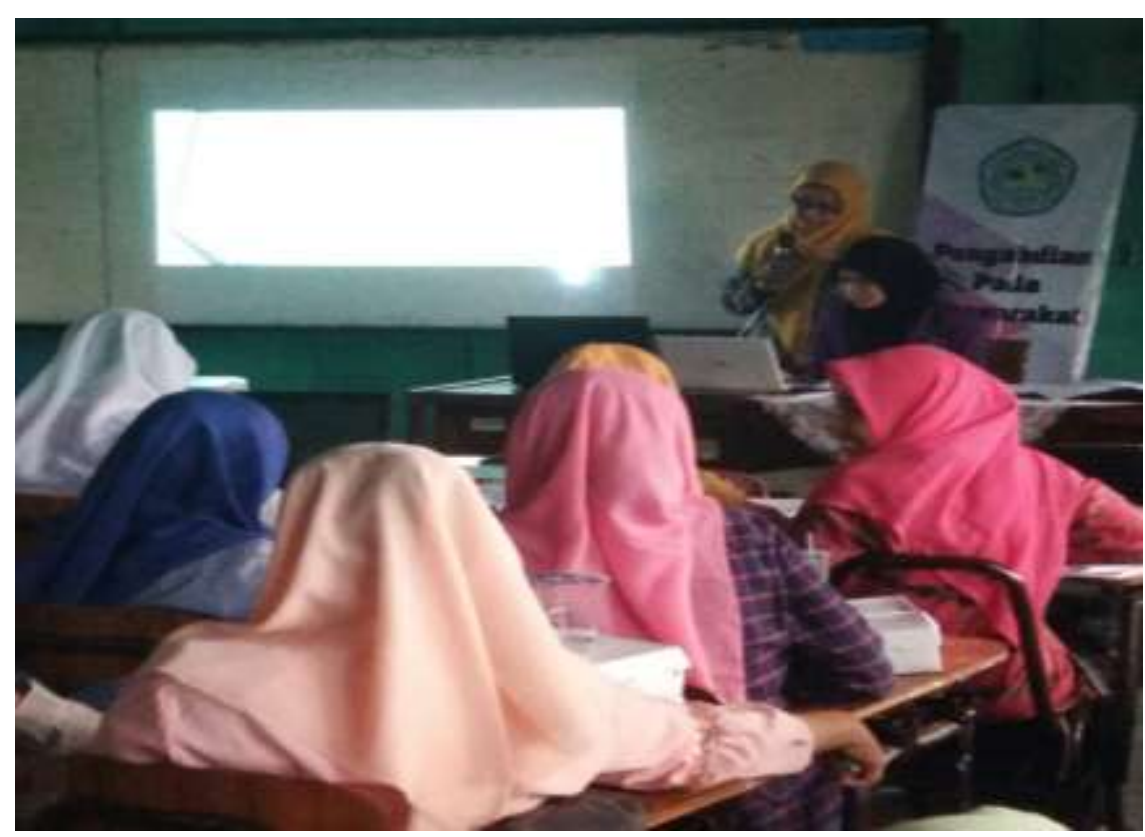

Gambar 6. Peserta memperhatikan penyampaian materi pelatihan mengunakan aplikasi software minitab 


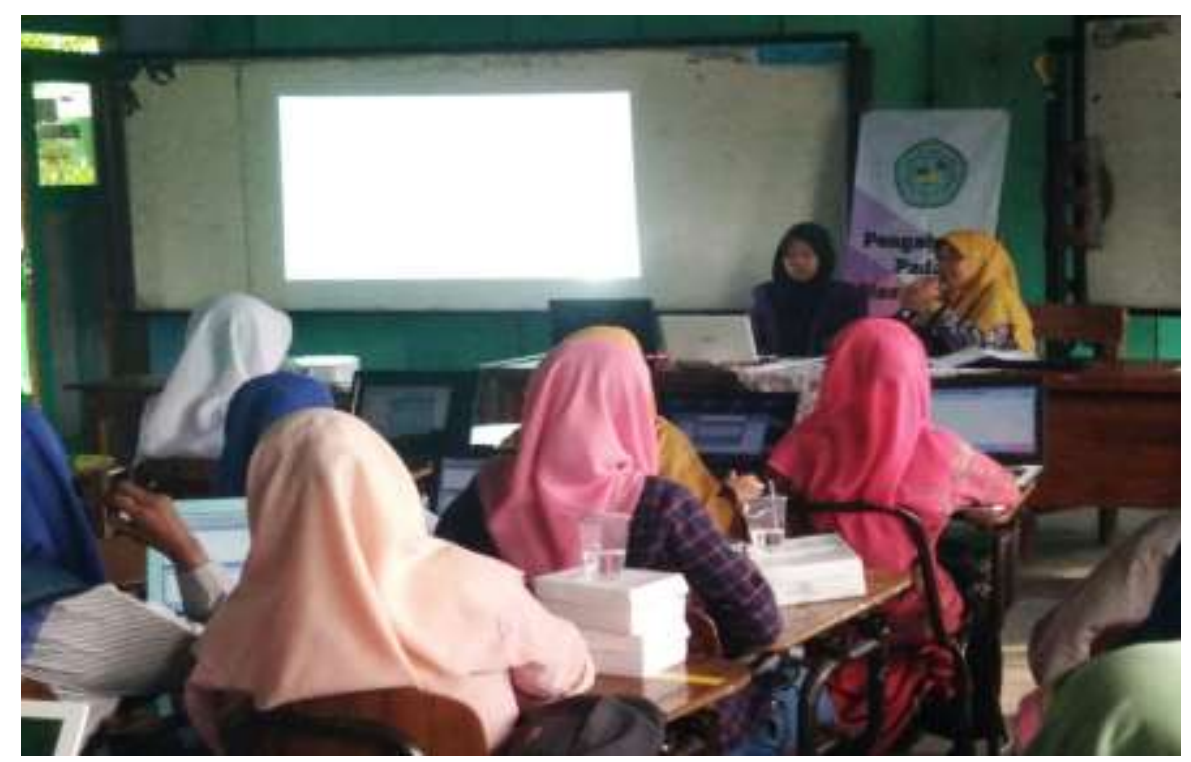

Gambar 7. Peserta memperhatikan penyampaian materi pelatihan mengunakan aplikasi software SPSS

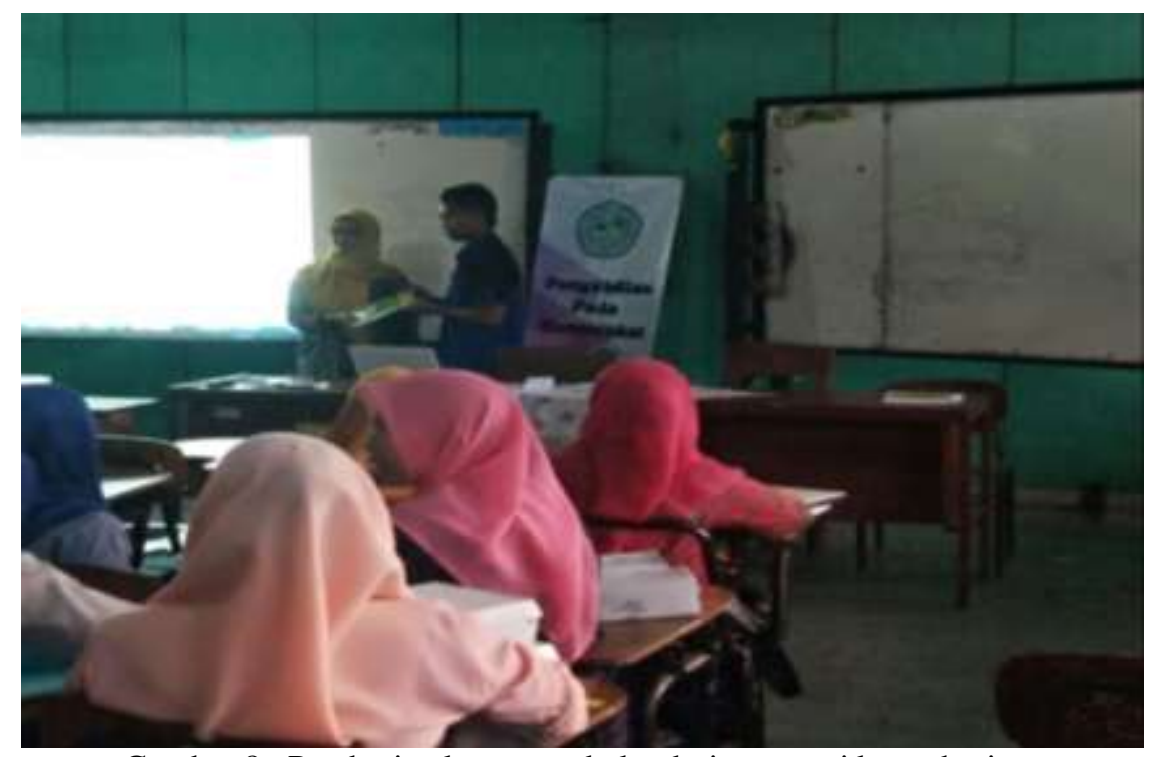

Gambar 8. Pemberian kenangan buku dari pemateri ke mahasiswa

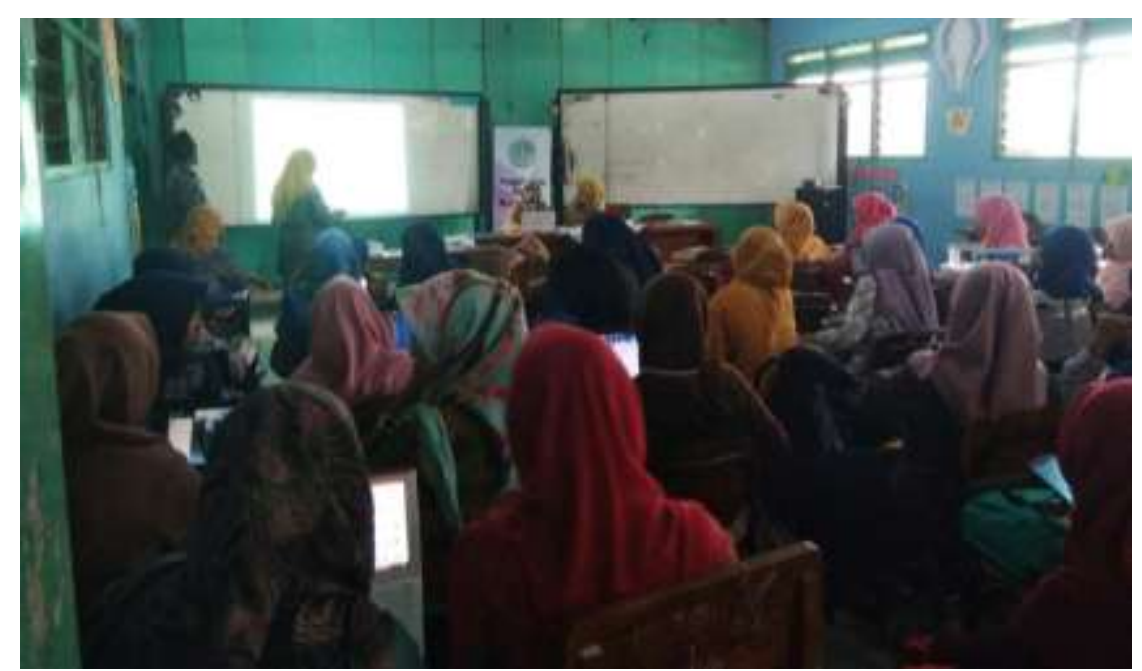

Gambar 9. Pemberian kenangan buku dari pemateri ke mahasiswi 


\section{SIMPULAN DAN SARAN}

Dari uraian kegiatan pengabdian masyarakat tersebut dapat diberikan beberapa kesimpulan dari kegiatan Pengabdian Pada Masyarakat (PPM) program studi Teknik Industri Sekolah Tinggi Teknik Qomaruddin (STTQ) Gresik di Jurusan PAI perguruan tinggi IAI Qomaruddin dapat memberikan nilai manfaat bagi mahasiswa Tugas Akhir, sehingga mampu:

a. Menencarinilai pemusaran data, nilai penyebaran data dan distribusi frekuensi yaitu beruda nilai-nilai Diskriptif dari suatu data.

b. Menentukan dugaan sampel terhadap populasi pada nilai rata-rata, nilai variansi dan nilai proporsi yang disebut dengan analisis Hipotesis.

c. Melihat seberapa besar pengaruh antara varibel bebas dengan variabel tak beabas yaitu berupa nilai korelasi, dan mencari seberapa besar pengaruh anatara varibel tersebut dalam bentuk model Regresi $\mathrm{Y}=$ $\alpha+\beta X+\varepsilon$.

d. Mencari nilai-nilai statistka dengan meneggunakan bantuan aplikasi software MINITAB dan SPSS.

\section{DAFTAR PUSTAKA}

Bilson Simamora. (2005). Analisis Multivariat Pemasaran Edisi Pertama. Jakarta: PT. Gramedia Pustaka Utama.

Daranggi. 2009. Pengembangan Usaha Kecil dan Menengah. Departemen Koperasi, Pengusaha Kecil dan Menengah, Jakarta.

Hillier, F. Dan Lieberman, G. 1994. Pengantar Riset Operasi. Jilid 1 Edisi Kelima, Penerbit Erlangga, Jakarta.

Hasan. I, 2002, Pokok-pokok Materi Pengambilan Keputusan, Ghalia Indonesia, Jakarta.

Johnson, R.A \& Wichern, DW. (1992). Applied Multivariate Statistical Analysis Third Edition. New Jersey: Prentice Hall International.

Jonathan Sarwono. (2007). Analisis Jalur untuk Riset Bisnis dengan SPSS. Yogyakarta : Andi Offset.
Kampus Besar Bahasa Indonesia, 2012. https://kbbi.web.id/ diakses pada 5 Maret 2016

Kotler, P. Gary, A. 2008. Prinsip-prinsip Pemasaran. Erlangga. Jakarta.

Mulyono, sri. 2004. Riset Operasi. Penerbit Erlangga, jakarta.

Saaty, T.L., 1990, The Analytic Hierarchy Process, McGraw-Hill, New York .

Siswanto, Operation Research, Jilid 1, Penerbit Erlangga.

Supranto. (2004). Analisis Multivariat Arti dan Interpretasi Edisi Pertama. Jakarta: Rineka Cipta.

Tjiptono, F. 2008. Strategi Pemasaran. Andi. Yogyakarta. 